Kolozsvár, 1998. március 20-21.

\title{
Beszédfelismerés alkalmazása a digitális vezérléstechnikában
}

\author{
Demeter Attila
}

\section{( SPEECH RECOGNITION ON DIGITAL CONTROL )}

The present work try to present the most often problems in development of a speech recognizing system. The selected method is the Hidden Markov Modell -based method, which is based on the probability rule of the russian scientist Markovnikov. This algorithm is used only in the decision strategy, so I present here the problems and methods used before it : the sampling, windowing, filtering,the LPC encoding techniques.

Az utobbi időben nagyon elterjedtek az intelligens beszédfelismerő programok amelyek kozul legnépszerübbek a Dragon Dictate,Voice Commander,stb.

Ezek a programok közönséges személyi számitógépeken futnak, óriási a szókeszletük és a felismerési arányuk is eléggé nagy , 85-90 százalék körül. Ám ez az arány elég kicsi ha egy komolyabb berendezés biztonságáról van szó, hiszen egy hibásan értelmezett parancs rossz eredményre vezethet, aminek következményei függnek a vezérelt folyamattól. Például egy szavakkal irányitott daru ha rossz helyre teszi le a darabot komoly balesetet okozhat.

Egy másik hátránya a Dragon Dictate-szerü programoknak az hogy elég nagy a hardverigényük , több megabyte memóriára és drága szamitógépekre van szükség hogy fussanak.

Egy lehetséges megoldás lenne korlátozások bevezetése:

- a szókészlet legyen kicsi ( néhány jól megkülönböztethető szó )

- a program legyen beszélőfüggő , vagyis csak egy személyre szabott , de azért könnyen átalakitható más személy hangja után

- a szavak ne legyenek folytonosak, vagyis minden szó után hagyjunk egy kis szünetet

Olyan programok (rendszerek) is léteznek amelyek ezek a követelmények szerint müködnek, és nagyon jól müködnek, de ezek a rendszerek mögött zseniális programozok hada áll és a biztonságos beszédfelismerés titka hétpecsétes titok egyelöre.

Léteznek különféle elméletek, de konkrét módszereket senki sem tesz kozzé. 
Több egyetemi központban különböző tanárokból és diákokból álló kutatócsoportok dolgoznak a megoldáson.

$\mathrm{Az}$ ideális platform egy ilyen programnak egy digitális jelprocesszr (DSP) lenne, amely biztositaná a hang valós idejü feldolgozását, és néhány kilobyte-nyi memóriája elég lenne a program és az adatok tárolására.

$\mathrm{Az}$ aktuális módszerek mindegyike teljesen numerikus feldolgozáson alapszik, tehát a hangjelet mintavételezni kell , a többi feladatot software végzi.

A következőkben egy ilyen tervet szeretnék bemutatni és egyuttal tisztázni a beszédfelismerésben felmerülő akadályokat.

Még mielött továbbmennénk szeretném megemliteni a beszédfelismerésben alkalmazott "divatos" technikákat :

1. Dynamic Time Warping (DTW) - nek nevezett megoldás a legrégibb, könnyen tanitható de a felismerési arány alacsony

2. Hidden Markov Modell (HMM) - legnépszerübb,a Markov-féle valószinüség elméleten alapszik,

3. Mesterséges neuronhálózatok - legelegánsabb módszer de ugyanakkor a legnagyobb hardverigenyü

Az általam választott módszer a Hidden Markov Modell, de ez a valószinüségszámitásokon alapuló algoritmus csak a döntési fázisban jelenik meg, addig még hosszú az út.

Az elv egyszerü : a kiadott parancsot a program osszehasonlitja az általa ismert parancsokkal, és ha valamelyikhez eléggé hasonlit akkor végrehajtja az annak megfelelő rutint. Ám a dolog nem ilyen egyszerü.

Egy beszédfelismerő rendszer részei:

1. Mintavételezö/Tartó áramkör (S\&H)

2. Ablakoló

3. Szürő

4. Kódoló

5. Minták

6. Komparátor

7. Döntési stratégia

8. Végrahajtó

$\mathrm{Az}$ emberi hang frekvenciája nem nagyobb a telefonvonalon átvitt sávnál , vagyis $3400-4000 \mathrm{~Hz}$ a maximum. Ezért a Shannon-törvénynek megfelelöen a mintavételezési frekvenciának a $8 \mathrm{kHz}$-es érték megfelelő , ami egy modern analóg-digitális átalakitónak gyerekjáték. 
Mivel a normális női hang frekvenciája nem nagyobb $800-900 \mathrm{~Hz}-n e ́ l$, a mintavételezett jelet megszürjük , ezáltal szép , zavaró harmonikusok nélküli jelet kapunk. A szürést természetesen egy digitális szürővel végezzük, egy 80 pontos $900 \mathrm{~Hz}$-nél vágó aluláteresztő FIR szürő megfelel a célnak.

Az ablakoló kiválaszt egy adott mennyiségü mintát és megszorozza egy ablakfügvénnyel ( háromszög, Hann, Bartlett, Hamming). Ennek a jelentőségét csak később látjuk majd meg.

A kódoló feladata a megszürt jel jellemzőinek megállapitása és a feldolgozásra váró adatok mennyiségének lecsökkentése.

A legnépszerübb kódoló módszer a lineáris predikció ( $\mathrm{LPC}=$ Linear Predictive Coding $)$, aminek az a lényege hogy a mintavételezett és megszürt hangjelet megközelitjük egy polinommal, vagyis a sok hangminta helyett csak egy polinom együtthatóit kell megjegyeznünk. Az együtthatók kiszámitására használt megoldás neve Le Roux-Gueguen módszer . Az LPC kódolás egy adott mennyisegü mintából kifejezi a hang jellemzöit :

a.) a hang periódusát

b.) a hang átlagos energiáját

c.) a hanghullám alakját a polinomiális együtthatók formájában

A hang periódusát komolyabb Fourier-analizis nélkül, egyszerü számitásokkal kapjuk meg , mig a hang átlagos energiáját átlagolással. Természetesen ezek az adatok csak egy adott ablaknyi hangmintára érvényesek.

A minták eredetileg tárolt szavak jellemzői , a minták száma megadja a felismerhető parancsok számát.

A komparátor blokk elvégzi az aktuális és a tárolt minták összehasonlitását. A komparátor blokk mükődését felügyeli a döntési stratégiát tartalmazó blokk vagyis a HMM -alapú algoritmus. Ez az algoritmus megadja az egyes szavak vagy szegmensek ( szórészletek ) egymás utáni következésének a valószinüségét.

Nem szabad elfeledkezni arról sem, hogy a szavak nem egyforma hosszúak, különböző számú szegmensből állnak, s igy nem tudjuk összehasonlitani őket. Erre a megoldás az interpolálás és a szegmensek tetszés szerinti kivágása , úgy is nevezhetjük hogy "normalizálás".

A végrehajtó blokk tartalmazza a különböző parancsoknak megfelelö rutinokat.

Egy adott személy sose mondja ki ugyanazt a szót ugyanúgy, eltérések mindig vannak a hanglejtésben , a hang magasságában, a szó hosszúságában. Ezért kell vigyázni a küszöbértékek, türéshatárok megálla- 
pitásánál. Egy kimondott szóban az egyetlen dolog ami nem változik az az hogy a magánhangzóknak általában periódusos jel felel meg , mig a mássalhangzókra nemperiodikus, zajszerü jelforma jellemző .

A beszédfelismerő programok alkalmazása komolyabb célokra még nem terjedt el , mivel a kéz még mindig biztosabb mint egy verbális parancs, de a kettő kombinációja nagyon megnövelné a vezérlés hatékonyságát.

Felhasznált irodalom:

1. H.N. Teodorescu,L.Buchholtzer,C.Posa : Comunicarea orala om-masina

Editura Tehnica 1986

2. Nat Seshan : A TMS320C30-Based Vocoder

Digital Signal Processing Solutions - Texas Instruments 1991

3. Implementation of an HMM-Based,Speaker-Independent Speech Recognition

System, Texas Instruments 1996

4. az Internetről leszedett 50-60 cikk/ötlet

Demeter Attila

diák

Petru Maior Egyetem , Marosvásárhely

Mérnöki kar , Ipari Automatizálás és Informatika 